\title{
Implementation of multicultural education through Sasambo Dance at the Universitas Mataram
}

\author{
Arif Widodo *, Nursaptini Nursaptini, Muhammad Erfan \\ Department of Primary Education, Teacher Training and Education Faculty, Universitas Mataram \\ Jl. Majapahit No.62, Gomong, Kec. Selaparang, Kota Mataram, 83115, Indonesia \\ * Corresponding Author. E-mail: arifwidodo@unram.ac.id
}

Received: 28 December 2020; Revised: 6 January 2021; Accepted: 21 January 2021

\begin{abstract}
The risk of conflict on a multicultural campus is enormous. There are many conflicts between students that are motivated by cultural problems. This study aims to describe the implementation of multicultural education at the University of Mataram. The unit of analysis in this study was students of elementary school teacher education programs. This research is urgent because students have cultural diversity. The research was designed in the form of qualitative research. The approach used is ethnography. The main problem examined in this study is how to implement multicultural education in the PGSD study program. The results of research on the implementation of multicultural education in the PGSD study program use the local wisdom approach. One of the local wisdom used is the Sasambo dance. Sasambo dance is a dance created by ethnic Sasak, Samawa, and Mbojo. The values contained in the Sasambo dance are unity, cooperation, and equality. This dance describes the spirit of unity, kinship, and equality. Three main ethnicities in the province of West Nusa Tenggara have been united in one family bond. Through the Sasambo dance students are taught that each tribe has the same position. Students are taught to respect each other and appreciate differences. The Sasambo dance has become an icon of the PGSD study program. Every student is required to learn and understand the meaning of the Sasambo dance.
\end{abstract}

Keywords: Multicultural Education, Sasambo Dance, local content.

How to Cite: Widodo, A., Nursaptini, N., \& Erfan, M. (2021). Implementation of multicultural education through Sasambo Dance at the University of Mataram. Jurnal Prima Edukasia, 9(2), 223-232. doi:https://doi.org/10.21831/jpe.v9i2.36992

\section{Introduction}

Multicultural education is not a new problem. Nowadays multicultural education is back in the spotlight. One reason is the increasing number of conflicts over cultural sentiments in various parts of the world. Reframing multicultural education in educational practice is based on social justice principles and values (Shannon-Baker, 2018). Democracy demands that every citizen has an equal position in law and government. Strengthening civil society and respect for human rights are some of the stages of realizing democracy. In addition, multicultural education has campaigned in the face of the swift currents of globalization. The clash between cultures and the flow of population migration in the $21 \mathrm{st}$ century is getting more massive. Migration flows are always followed by cultural penetration (Widodo, Royana, et al., 2020). Cultural penetration often creates conflict. The increasing diversity of cultural diversity makes some people experience cultural shock. Not a few groups of people feel unable to accept differences. The implication is that there is an attitude of discrimination and intolerance. Therefore, multicultural education is here to offer a solution. According to an expert, multicultural education in the 21 st century is needed to balance advanced civilizations in unity and difference (Banks \& Banks, 2019). Creativity and new approaches are needed in implementing multicultural education in educational units, especially if the educational environment has a different cultural background.

Integrating multicultural-based learning and education services in colleges and universities is a very important issue (O'Grady, 2014). This is even more so if the high school or university has culturally diverse students. Multicultural-based universities have a huge potential for conflict. One university that has a fairly high cultural variation is Mataram University. Mataram University is the main reference for most students in the Eastern Indonesia region in studying. The implication is that students from various regions come together to bring their respective cultural identities. Three major tribes have the majority 
Jurnal Prima Edukasia, 9 (2), 2021 - 224

Arif Widodo, Nursaptini Nursaptini, Muhammad Erfan

in the university environment. The three tribes are the Sasak, Samawa, and Mbojo tribes. The interaction between the three major tribes has the potential to cause conflict. Besides that, the attraction possessed by the island of Lombok makes many people flock to migrate to this area. Not only the indigenous people of NTB but various tribes from all over the archipelago also inhabit this area. Cultural clashes and competition for life often lead to conflicts. Conflicts with ethnic nuances outside the campus have the potential to be carried over to the campus. This makes university managers have to think hard so that ethnic conflicts do not occur within the university. Therefore, this research will examine how the implementation of multicultural education at the University of Mataram. Through this research, it is hoped that it can inspire actors in the world of education in creating multicultural education.

Multicultural education is designed to provide fair learning services to all students. In multicultural education, racial and cultural differences are no longer a problem. This approach aims to create consensus, mutual respect, and foster cultural pluralism in racial societies (Clark, 2013). Multicultural education is also used as an approach to improving education management. The desired change is the realization of equality, social justice, and democracy (Rukiyati, 2012). The achievement of consensus and respect for different cultural groups is the main principle. The principle of multicultural education has the aim that every school provides equal opportunities for every student to obtain the knowledge needed regardless of ethnic and racial differences. Multicultural education as an approach seeks to transform progressively and holistically. The multicultural education movement criticizes various failures, weaknesses, and discrimination in education. Multicultural education can be used as a social engineering instrument (Supriatin \& Nasution, 2017). In this way, schools can play a role in instilling awareness in the community about multiculturalism. The community can be taught to always work together to achieve goals by putting aside all differences. Theoretically, the meaning of multicultural education is still ambiguous. There is a disconnect between theory and daily practice in the classroom (Saint-Hilaire, 2014). However, the implementation of multicultural education must be carried out.

Discussing multicultural education the main references that are sought are Banks and Banks (2019) is a leading pioneer of multicultural education. This figure is often referred to as the father of multicultural education. If examined further, basically the thoughts of national figures in the field of multicultural education are no less great than Banks. Ki Hadjar Dewantara has introduced the concept of multicultural education through a system of among, Tut Wuri Handayani, and Panca Dharma (Muthoifin, 2015). Banks' thinking is motivated by the diversity of the American population which leads to discrimination. His movement demands that educational institutions provide equal opportunities to everyone, regardless of ethnic origin, culture, and gender (Amirin, 2013). Banks and Banks (2019) thoughts on multicultural education can be linked to the American dream movement. This movement is fighting for the ideal form of democracy. This understanding dreams of success and prosperity based on equality and equal opportunities regardless of differences in social and cultural elements (Sleeter, 2011). Likewise with Ki Hadjar Dewantara based his thoughts on the cultural diversity of the Indonesian people. Ki Hadjar Dewantara in his education concept uses the term humanizing humans. In its implementation, Ki Hadjar Dewantara treats students fairly regardless of cultural background, status, and other indicators of social class. However, most of us don't realize it or don't even know it. The two concepts of multicultural thought place humanity as a basis for thinking and uphold social justice in racial and cultural equality (Grant \& Sleeter, 2011). Besides, the concept of education that is often forgotten is multicultural education that is contained in the values of local wisdom (Widodo, 2020). There are many local pearls of wisdom that teach about the character (Widodo, Umar, et al., 2020). One of the values of local wisdom also contains multiculturalism education. Therefore, learning multicultural education does not have to think far abroad because multicultural education is owned by the Indonesian nation, especially education in the philosophy of life inherited from our ancestors. Multicultural education is not a threat to the existence of regional culture. Normative multicultural education can strengthen regional cultural identity (Mania, 2010). The accumulation of this regional culture will form a national culture without losing the identity of each. Therefore, it requires the cooperation of many parties in implementing multicultural education. Teachers must involve families, school personnel, and administrators in implementing multicultural education (Manning et al., 2017).

Several previous studies examine multicultural education. However, most of it is still a concept. There are not many studies that discuss the implementation of multicultural education in real practice. Some of these studies, one of which discusses the implementation of multicultural education which is associated with attitudes of religious tolerance. In this study, it was explained that the implementation 
Jurnal Prima Edukasia, 9 (2), 2021 - 225

Arif Widodo, Nursaptini Nursaptini, Muhammad Erfan

of multicultural education can increase attitudes of religious tolerance, increase the spirit of cooperation, and increase brotherhood (Elfandari, 2016). Subsequent research discusses the implementation of multicultural education in inclusive schools. In this study, it was revealed that multicultural education in inclusive schools can be implemented in learning and outside learning (Widodo \& Umar, 2020). There is one more research that is unique. This study examines multicultural-based learning of cultural arts. In this study, it was revealed that the three elements of art consisting of aesthetics, appreciation, and humanization can be used as character education (Pradana, 2018). These three elements can unite differences to prevent conflicts due to ethnic and cultural differences. In multicultural-based art, learning prioritizes awareness of pluralism and cultural heterogeneity.

As a comparison, several results of research on multicultural education abroad will be presented. One of the studies states that in the implementation of multicultural education in special education several problems must be resolved, including the problem of representation of children with special needs, cultural misunderstandings, and tensions between home and school (Irvine, 2012). In this study, it is recommended that teachers make special preparations in serving children with disabilities and children with different cultural backgrounds. Subsequent research related to education in multi-ethnic and multi-religious countries. In the study, it was stated that educational policy had reflected the concept of multicultural education (Arphattananon, 2018). Schools provide opportunities for migrant students to get an education. The Ministry of Education also allows individual schools to implement regulations according to the cultural diversity of their students. The curriculum includes references to various cultures and study materials are designed so that students can live in harmony with people of different cultures. Subsequent research examines the relationship between the experience of diversity and the thinking ability of citizenship. The results of this study reveal that the level of participation in learning services, multicultural courses, the interaction between cultural racial awareness workshops, the interaction between students within the faculty, and racial equality on campus has a significant and positive effect in shaping student citizenship thinking (Cole \& Zhou, 2014).

Some of the above studies have explained the importance of multicultural education. This study aims to determine the implementation of multicultural education at the University of Mataram. Multicultural education in a university environment is a form of cultural conflict resolution. Through this research, it is hoped that the multicultural education model that has been implemented can be an example in the development of multicultural education in general.

\section{Methods}

Research location at the University of Mataram. The unit of analysis in this research is the PGSD study program. The research was conducted in 2020. This research was designed in the form of qualitative research. This type of research is used to reveal reality and meaning naturally without any treatment. The approach used is ethnography. Through an ethnographic approach, researchers describe facts in detail and report objectively (Creswell, 2013). Reports are based on observations and use of the other five senses. Researchers make use of all five senses to record the existing reality. The research stages include conducting a preliminary study, determining issues, compiling research instruments, collecting data, and compiling reports. The most important stage is the stage of interpretation of the phenomena that exist in the research location. Data collection was carried out by using in-depth interviews and participatory observation. The objects observed in this study include activities, behaviors, events, and other objects related to research. Observations are made directly and participate in the process of implementing multicultural education in the campus environment. In-depth interviews are used to gather information related to campus culture and local cultural values that apply in the NTB area. In-depth exploration is carried out to understand the hidden meanings in the local culture, one of which is the Sasambo dance. The main informants in this study included lecturers and students of PGSD, Mataram University. Supporting informants in this study were community leaders. The data analysis technique adopted the Miles et al. (2014) model, namely data reduction, data presentation, and conclusion drawing. To test the validity of the data using source triangulation. Information from one informant compared with another. 
Jurnal Prima Edukasia, 9 (2), 2021 - 226

Arif Widodo, Nursaptini Nursaptini, Muhammad Erfan

\section{Result and Discussion}

Based on observations it can be seen that the implementation of multicultural education in the campus environment uses a local wisdom approach. This approach is used because the people of NTB have local wisdom that contains the values of multicultural education. The implementation of multicultural education adopts the values of local wisdom prevailing in society. One of the multicultural education in the NTB community is manifested in the form of dance. The dance is named Sasambo dance. The name Sasambo was taken from the abbreviation of the names of the tribes in the NTB province. Sasambo is an abbreviation of Sasak, Samawa, and Mbojo. Three major tribes in NTB. This dance was created specifically as a means of unifying the three ethnic groups. The three cultural figures from the three tribes formed a consensus. This is done to reduce the occurrence of friction due to competition in the political, economic, and social fields. As a form of consensus, a dance was created as a symbol of unity. Therefore the name of the dance is taken from the first names of the three tribes. The use of the name Sasambo in NTB is not only a dance name but is also used for the names of products, activities, and communities in NTB. As one example Sasambo is also used to give the name of a unique batik NTB. Sasambo TV, Sasambo batik, and Sasambo shop are some examples of the use of the name Sasambo in the life of the NTB community. From this, it can be understood that consensus in society has formed. This is proven by the pride in using the name Sasambo in all community activities. Therefore the implementation of multicultural education in the campus environment is relatively easier because in the community a consensus has been formed.

Sasambo dance performances are always accompanied by Sasambo music. The musical instruments used to accompany the Sasambo dance consisted of the Beleq Drum, Rebana Sakeco, and Gambo Violin. Beleq drum is a musical instrument of the Sasak tribe. Rebana Sakeco is a musical instrument of the Samawa tribe. The Gambo Violin is a proud musical instrument of the Mbojo tribe. Sasambo music stimulates everyone who hears it always wants to dance. The rhythm created in Sasambo music has a cheerful atmosphere. A happy atmosphere symbolizes happiness because there has been harmony and togetherness. The spirit of togetherness in Sasambo dance is always instilled in every student's behavior in the campus environment. The sense of brotherhood can be seen when students perform Sasambo dance performances. The students of different ethnic backgrounds were skilled in dancing Sasambo. The three tribes blend so that there is no longer a gap between them. Considering the Sasambo dance is performed in groups, the awkwardness between them is no longer visible. Three different ethnic cultures in the campus environment can be united in a dance. This is inseparable from the policy of the study program manager who requires each student to have the ability to dance Sasambo.

Implementation of multicultural education through Sasambo dance

Sasambo dance is used as a means of implementing multicultural education in the campus environment, especially in primary school teacher education programs. This is important because the prospective elementary school teachers who graduate in the program have a very important role in shaping their character in the future. They must be role models and multicultural education agents in the future. There are several ways to implement dance as a means of multicultural education, one of which is through integration in the subject. One of the courses designed as a multicultural education facility is a regional art and culture course. The curriculum of the primary school education program is specifically designed so that the course can be used as a medium of multicultural education. Through this course, students are taught about aesthetic values, pluralism, and humanism in a dance.

Regional arts courses are one of the compulsory subjects in the elementary school teacher education program. Students cannot finish college before taking this course. One of the competencies students must master in this subject is Sasambo dancing skills. This is done as a manifestation of the commitment of the elementary school teacher education program in implementing multicultural education in the campus environment. Through integration in subjects, the seriousness of students in learning dance can be controlled, so that at the end of the lecture students are truly skilled in Sasambo dancing. By having Sasambo dancing skills students are expected to live up to the multicultural values and peace messages contained in the dance. The appreciation and understanding of multicultural messages are also expected to shape the attitudes and behavior of students in the campus environment. Expected attitudes and behaviors can maintain harmony amid diversity. Besides that students as multicultural education agents in the future are expected to be able to teach and give examples of the beauty of diversity in 
Jurnal Prima Edukasia, 9 (2), 2021 - 227

Arif Widodo, Nursaptini Nursaptini, Muhammad Erfan

dance. Students as prospective teachers can teach educational values through dance to their students in the future.

Implementation of Sasambo dance as a medium of multicultural education is not only limited to subjects. Sasambo dance has become an icon of elementary school teacher education programs. Sasambo dance becomes a mandatory dance in every activity at the university. This dance is often performed by students in various festival activities or dance competitions between faculties. The Sasambo dance also functions as a welcome dance at the University. Welcoming large guests or welcoming new students usually uses Sasambo dance. These various efforts were carried out as an effort to introduce Sasambo dance which is very thick with the values of multiculturalism. New students are offered a multicultural dance so that the national spirit grows early. They are expected to be familiar with the diversity that exists in universities. This is important because the readiness to accept differences risks creating conflicts between students. Moreover, if the student is accustomed to a homogeneous society will be surprised by the heterogeneous new environment. Therefore, the introduction of multicultural culture from the beginning is very important.

Multicultural Values in the Sasambo dance

Sasambo dance is performed in groups. Personnel involved in Sasambo dance performances usually consist of various tribes. Following the name of the Sasambo dance (Sasak, Samawa, and Mbojo), those involved in the show are the three tribes. Based on the results of an interview with one of the Sasambo culturalists this dance was created as a unifier of the three tribes in NTB. The goal is to eliminate the gap between one tribe and another. With this equality, there is no longer a tribe that is considered the most superior. All tribes have the same position in all fields. Therefore, the name Sasambo in the dance aims to embrace the three tribes. The name Sasambo used in this dance is short for tribal names in NTB. This needs to be emphasized considering the name Sasambo is also one of the Sulawesi regional song names. However, the provision of Sasambo in NTB has nothing to do with Sasambo in Sulawesi. It's just that both of them coincidentally have the same name. Historically Sasambo in Sulawesi existed before the use of the name Sasambo in NTB. Sasambo's dance, music, and batik creations from a political perspective are an effort to unite the three ethnic groups in one province. This is inseparable from the issue of regional expansion in NTB. Sumbawa Island, inhabited by the Samawa and Mbojo tribes, is said to make its province. Therefore, the Sasambo icon was made to form the identities of the three tribes in one bond. Sasambo cultural figures gathered to make art creations that include these three tribes. With the formation of the Sasambo identity, the issue of regional expansion is no longer heard. This proves that cultural identity formed through art can unite different ethnicities in all fields. The newly formed identity has united various ethnicities in one family bond. This indicates that there has been a consensus between the three tribes. The consequence is that the three tribes have a position, opportunity, and equality in the political, economic, and socio-cultural fields.

Forming a new identity through art is not without reason. One reason is that the people of NTB have high artistic tastes. Many local wisdom values are expressed through art, one of them is music and dance. The values of local wisdom still hold the life of the people of NTB. Some local wisdom that is upheld by the community is togetherness, family values. peace, justice, tolerance, and mutual respect. Art has universal values, namely aesthetic values. The art creations by Sasambo culture have proven that beauty in art can unite differences. The Sasambo culture is good at creating without losing the local wisdom of the community. Even creations made strengthen the values of local wisdom, one of which is found in Sasambo dance. The dance, named Sasambo, is one of the artistic creations created by cultural figures from three ethnicities. In addition to the creation of cultural dances, dancers also perform music and Sasambo songs.

Sasambo dance performances are always accompanied by Sasambo music. Sasambo Music was also created as a symbol of unity. Sasambo music creations are done by combining various musical instruments owned by each ethnic group in NTB. Beleq drum, Rebana Sakeco, and Gambo violin are combined to produce beautiful tunes. Each musical instrument represents the existence of each ethnic group. The beautiful combination of musical instruments from various ethnicities symbolizes the beauty of diversity. If Sasambo music is played, every ear that hears it will dissolve into happiness. Ethnic differences have been ignored. Everyone will unite in beautiful music.

Sasambo dance is accompanied by Sasambo music but also accompanied by Sasambo song. Sasambo song lyrics are also created using the language of each ethnicity. The selection of words that 
Jurnal Prima Edukasia, 9 (2), 2021 - 228

Arif Widodo, Nursaptini Nursaptini, Muhammad Erfan

match makes Sasambo songs very pleasant to hear. No discrepancies are seen even though in one song there are several languages. Incredible lyrics creation in Sasambo music. The atmosphere of excitement is illustrated by the lyrics of Sasambo songs. The message to be conveyed is to invite everyone to dance and forget for a moment the various problems encountered. The message was repeated three times in different languages. Sasak language lyrics in the song read "Gendang Beleq, Rebana Sakeco, Violin Gambo Pinaq Ite Ngigel" which means "Gendang Beleq Rebana Sakeco and Violin Gambo make us dance". The message was also conveyed in the Samawa language which reads "sesai pelangan turit irama Sasambo....tu goyang rapina ke toha". If translated the lyrics means "anyone who joins the Sasambo rhythm... let's sway to get good". The invitation to dance was also repeated in Mbojo which read "maita kadihi ade kambora susa ra darura tasama rawa ro patu tenggo jasmani rohani". If translated the lyrics mean "let's have fun eliminating the difficulties and burdens, together we sing, so that the strong physical and heart". The three languages in the lyrics are the same, which is to invite joy and maintain harmony in differences.

Sasambo song lyrics are made simple enough so that they are easily memorized by every listener. In Sasambo song lyrics there is also a message of multicultural values. This can be seen from the use of three languages in one song. Also in the lyrics clearly stated Sasambo music instruments that include Sasak, Samawa, and Mbojo tribes. Every element owned by each tribe is modified into a very beautiful work of art. Ranging from musical instruments, languages, and even clothing that is used. The use of musical instruments and languages from various ethnicities in one song reflects harmony, cooperation, kinship, social justice, and ethnic equality. This shows that in addition to prioritizing the values of beauty in art creations it also brings multicultural teachings.

Very beautiful art creations and contain multicultural messages in Sasambo dance is very unique. This kind of creation is rarely found. It could be that this kind of art creation only exists in NTB. Sasambo music and Sasambo songs are a unity with the Sasambo dance. The existence of these three elements cannot be separated. Therefore, if mentioning Sasambo dance means that it includes Sasambo music and lyrics. These three elements of art are always displayed at the same time. Sasambo dance is not complete without Sasambo music. These three elements have the same mission of uniting three different ethnicities in NTB. Along with the development and creative power is quite high, Sasambo music is also used to accompany the Sasambo gymnastics. However, this creation does not matter. The more Sasambo nuanced artistic creations the better it is to establish inter-ethnic harmony. Therefore, it is not surprising that everything in NTB is often given the name Sasambo, one of which is the creation of batik which is named Sasambo batik.

\section{Discussion}

The use of cultural approaches in multicultural education has been commonly used. There is a study that states that cultural heritage can be used to implement multicultural education (Carjuzaa et al., 2010). Heritage needs to be preserved so that the younger generation is not cut off from the cultural values of historical heritage (Nursaptini, Widodo, et al., 2020). If viewed from the historical aspect, the harmony of the people of Lombok has existed for hundreds of years ago. At that time most of the island of Lombok was still controlled by the Balinese kingdom. Until now, one can still find a form of harmony shown by the Balinese Hindu people of Lombok descent with the Sasak people who are generally Muslim. The two groups each year carry out a joint ritual called the Topat War ritual (Yasa, 2020). In this ritual, Hindus and Muslims perform the ritual at the same time and in the same place. Both groups can perform the rituals peacefully without anyone feeling disturbed. This shows that the Sasak people are accustomed to dealing with differences. This kind of community condition is a very valuable asset in the implementation of multicultural education. University managers adopt the spirit of multiculturalism that has been built in society.

Multicultural education that is implemented in the university environment in essence already exists in society. University managers only modify and adapt to campus culture. The university also maintains intensive communication with community and religious leaders to create harmony on campus. The entire academic community uses community culture as a means of implementing multicultural education. Seeing a phenomenon like this, it can be understood that the implementation of multicultural education can be done flexibly. Multicultural education does not have to stand alone as a subject. This is following previous research which states that multicultural education can be implemented in an integrated manner and empowered through school culture (Supriatin \& Nasution, 2017). 
Jurnal Prima Edukasia, 9 (2), 2021 - 229

Arif Widodo, Nursaptini Nursaptini, Muhammad Erfan

The implementation of multicultural education at the University through the Sasambo dance is one way of shaping the university culture. Multicultural education always encourages educational institutions to internalize social awareness and teamwork skills in the context of diversity (Nuraini, 2017). In a study, it was stated that the successful implementation of multicultural education in educational institutions depends on the policies and commitment of the people in it (Firdaus et al., 2020). Therefore, making the Sasambo dance an icon of the study program proves that this university has a high commitment to multicultural education. The entire academic community is required to understand and live up to the multicultural values that exist in Sasambo dance. This method is quite effective. Different ethnicities can be united in a beautiful work of art. This shows that social construction in a multicultural society has been successfully carried out (Sukamto et al., 2018). Ethnic differences are no longer a problem. It is rare to find ethnic conflicts of interest in the university environment. Each ethnic group can be aware of their respective roles and positions. They realized that, regardless of their ethnicity, they were still in one family, namely the Sasambo family.

Dance has a very important role in multicultural education and the development of responsive culture-based education (Melchior, 2011). When viewed from the aspect of art, a dance does have elements of multicultural education. Through dance, children can explore and express their own culture and the culture of others. Learning diverse dances can indirectly introduce other ethnic cultures to students. This method is an effective solution in fostering an understanding of cultural pluralism among students (Ashley, 2014). Each student can carry out social interactions to get to know each other's culture. The ability to do social interaction is one indicator of students' social skills (Sutisna et al., 2020). Mastery of social skills is as important as mastery of material contained in classroom learning (Supriyanta et al., 2019). Through dance, students can also understand and accept certain cultural practices in diversity (Banerjee, 2013). As an art, dance can be used to unite diversity (Sensoy et al., 2010). In a study mentioned, one of the most diverse countries is Australia. In this study, it was revealed that Australia uses dance education as a strong platform to spread and promote togetherness (Joseph, 2013). Prospective teachers in these countries have been trained to have multicultural dance skills. This shows that dance has enormous benefits in the field of multicultural education. Incorporating dance elements in learning is considered quite effective in increasing students' knowledge and social attitudes (Smith et al., 2016). The collaboration of learning dance and the integration of dance into learning can improve the closeness of the relationship between teachers and students and students with one another (Melchior, 2011). Besides, the integration of local content in learning activities is believed to improve student learning outcomes (Suryanti et al., 2020). This is following a study that states that through dance students can think critically in responding to differences to form an attitude of tolerance and mutual respect (Islamiah, 2018). With tolerance, harmony and unity will be realized (Widodo, Maulyda, et al., 2020). However, the commitment of educational institutions and the involvement of local community leaders in realizing harmony is very important. Good cooperation is needed so that the educational mission can be achieved (Nursaptini, Anar, et al., 2020). In this case, it is the mission of multicultural education.

\section{Conclusion}

The implementation of multicultural education at Mataram University uses a local wisdom approach. Campus culture is built based on cultural values that exist in the community. One way is to take advantage of dance creations. The dance is given the name Sasambo dance which means Sasak, Samawa, and Mbojo. Sasambo dance is a symbol of the unity of the Sasak, Samawa, and Mbojo tribes. In its implementation, Sasambo dance becomes a compulsory dance that must be mastered by students. Multicultural education in Sasambo dance is integrated into regional arts and culture courses. Besides, the Sasambo dance has also become an icon of the PGSD study program and a welcome dance in every festival. Every student is required to learn and live the Sasambo dance. The values contained in the Sasambo dance include the spirit of unity, harmony, cooperation, kinship, social justice, and ethnic equality. This dance describes joy and happiness regardless of ethnic differences. The ethical and aesthetic values contained in Sasambo dance can unite different ethnicities. Through the Sasambo dance, students are taught that every ethnicity has the same position. Students are made aware that regardless of their ethnicity they are one family, namely the Sasambo family. They are expected to respect and appreciate diversity to create harmony in the campus environment. The implementation of multicultural education is important. Moreover, as a student-teacher candidates must be a good example for their students in the 
Jurnal Prima Edukasia, 9 (2), 2021 - 230

Arif Widodo, Nursaptini Nursaptini, Muhammad Erfan

future. Exemplary is needed, especially in instilling the values of diversity character in elementary schools.

\section{References}

Amirin, T. M. (2013). Implementasi pendekatan pendidikan multikultural kontekstual berbasis kearifan lokal di Indonesia. Jurnal Pembangunan Pendidikan: Fondasi Dan Aplikasi, 1(1). https://doi.org/10.21831/jppfa.v1i1.1047

Arphattananon, T. (2018). Multicultural education in Thailand. Intercultural Education, 29(2), 149162. https://doi.org/10.1080/14675986.2018.1430020

Ashley, L. (2014). Encountering challenges in teacher education: developing culturally pluralist pedagogy when teaching dance from contextual perspectives in New Zealand. Research in Dance Education, 15(3), 254-270. https://doi.org/10.1080/14647893.2014.910186

Banerjee, S. (2013). Adaptation of Bharatanatyam dance pedagogy for multicultural classrooms: questions and relevance in a North American university setting. Research in Dance Education, 14(1), 20-38. https://doi.org/10.1080/14647893.2012.712102

Banks, J. A., \& Banks, C. A. M. (2019). Multicultural education: Issues and perspectives (J. A. Banks \& C. A. M. Banks (Eds.); 10th ed.). John Wiley \& Sons.

Carjuzaa, J., Jetty, M., Munson, M., \& Veltkamp, T. (2010). Montana's Indian education for all: Applying multicultural education theory. Multicultural Perspectives, 12(4), 192-198. https://doi.org/10.1080/15210960.2010.527585

Clark, C. (2013). Multicultural education. In Multicultural America: A Multimedia Encyclopedia. SAGE Publications, Inc. https://doi.org/10.4135/9781452276274.n593

Cole, D., \& Zhou, J. (2014). Do diversity experiences help college students become more civically minded? Applying banks' multicultural education framework. Innovative Higher Education, 39(2), 109-121. https://doi.org/10.1007/s10755-013-9268-x

Creswell, J. W. (2013). Educational research: Planning, conducting, and evaluating quantitative and qualitative research. Pearson.

Elfandari, N. (2016). The implementation of multicultural education in increasing tolerance of religiousity and socialization of society at Desa Balun Turi Lamongan. Universitas Islam Negeri Maulana Malik Ibrahim.

Firdaus, F., Anggreta, D. K., \& Yasin, F. (2020). Internalizing multiculturalism values through education: Anticipatory strategies for multicultural problems and intolerance in Indonesia. Jurnal Antropologi: Isu-Isu Sosial Budaya, 22(1), 131. https://doi.org/10.25077/jantro.v22.n1.p131-141.2020

Grant, C. A., \& Sleeter, C. E. (2011). Doing multicultural education for achievement and equity (2nd ed.). Routledge.

Irvine, J. J. (2012). Complex relationships between multicultural education and special education. Journal of Teacher Education, 63(4), 268-274. https://doi.org/10.1177/0022487112447113

Islamiah, R. (2018). The implementation of multicultural education to social studies learning through art and culture on 21. International Seminar on Social Studies and History Education (ISSSHE), $351-360$.

Joseph, D. (2013). Moving to the rhythm of Africa: A case study of a tertiary educator's understanding of multicultural dance in teacher education. Journal of Education and Training Studies, 1(1). https://doi.org/10.11114/jets.v1i1.82

Mania, S. (2010). Implementasi pendidikan multikultural dalam pembelajaran. Lentera Pendidikan : Jurnal Ilmu Tarbiyah Dan Keguruan, 13(1), 78-91. https://doi.org/10.24252/lp.2010v13n1a6

Manning, M. L., Baruth, L. G., \& Lee, G. L. (2017). Multicultural education of children and adolescents (6th ed.). Taylor \& Francis.

Melchior, E. (2011). Culturally responsive dance pedagogy in the primary classroom. Research in Dance Education, 12(2), 119-135. https://doi.org/10.1080/14647893.2011.575223 
Jurnal Prima Edukasia, 9 (2), 2021 - 231

Arif Widodo, Nursaptini Nursaptini, Muhammad Erfan

Miles, M. B., Huberman, A. M., \& Saldaña, J. (2014). Qualitative data analysis: A methods sourcebook. Sage.

Muthoifin, M. (2015). Pemikiran pendidikan multikultural Ki Hadjar Dewantara. Intizar, 21(2), 299_ 320. http://jurnal.radenfatah.ac.id/index.php/intizar/article/view/314

Nuraini, F. (2017). Local culture implementation in multicultural education practice for early childhood. Proceedings of the 3rd International Conference on Early Childhood Education (ICECE 2016). https://doi.org/10.2991/icece-16.2017.37

Nursaptini, N., Anar, A. P., Indraswati, D., Wiododo, A., Novitasari, S., \& Sutisna, D. (2020). School operational assistance and challenges of communities' participation at madrasah tsanawiyah in Central Lombok. Proceedings of the 1st Annual Conference on Education and Social Sciences (ACCESS 2019), 465(Access 2019), 279-282. https://doi.org/10.2991/assehr.k.200827.070

Nursaptini, N., Widodo, A., Novitasari, S., \& Anar, A. P. (2020). Festival Bau Nyale sebagai pengenalan dan pelestarian budaya. Cakrawala, 9(1), 85-96.

O'Grady, C. R. (2014). Integrating service learning and multicultural education in colleges and universities. Routledge.

Pradana, R. W. B. (2018). Menumbuhkan karakter peserta didik melalui pendidikan multikultural pada pembelajaran seni budaya. Proceedings of the ICECRS, 1(3), 95-104. https://doi.org/10.21070/picecrs.v1i3.1384

Rukiyati, R. (2012). Landasan dan implementasi pendidikan multikultural di Indonesia. HUMANIKA, 12(1), 50-67. https://doi.org/10.21831/hum.v12i1.3651

Saint-Hilaire, L. A. (2014). So, how do I teach them? Understanding multicultural education and culturally relevant pedagogy. Reflective Practice, 15(5), 592-602. https://doi.org/10.1080/14623943.2014.900026

Sensoy, O., Sanghera, R., Parmar, G., Parhar, N., Nosyk, L., \& Anderson, M. (2010). Moving beyond "dance, dress, and dining" in multicultural Canada. International Journal of Multicultural Education, 12(1). https://doi.org/10.18251/ijme.v12i1.248

Shannon-Baker, P. (2018). A multicultural education praxis: integrating past and present, living theories, and practice. International Journal of Multicultural Education, 20(1), 48-66. https://doi.org/10.18251/ijme.v20i1.1518

Sleeter, C. E. (2011). Keepers of the American dream: A study of staff development and multicultural education (121st ed.). Routledge.

Smith, K., Kulinna, P. H., Vissicaro, P., \& Fredrickson, L. (2016). Anthropology, dance, and education: Integrated curriculum in social studies. The Social Studies, 107(1), 28-37. https://doi.org/10.1080/00377996.2015.1094725

Sukamto, S., Ruja, I. N., \& Purnomo, A. (2018). Social construction on cultural multiculturalism. Jurnal Teori Dan Praksis Pembelajaran IPS, 3(1), 59-68. https://doi.org/10.17977/um022v3i12018p059

Supriatin, A., \& Nasution, A. R. (2017). The implementation of multicultural education in the educational practices in Indonesia. Elementary: Jurnal Ilmiah Pendidikan Dasar, 3(1), 1. https://doi.org/10.32332/elementary.v3i1.785

Supriyanta, E. Y., Mustadi, A., Wangid, M. N., \& Suhardi. (2019). Sociocultural-based reflective picture storybook: Urgency in social skill development. Proceedings of the 3rd International Conference on Current Issues in Education (ICCIE 2018), 326(Iccie 2018), 162-166. https://doi.org/10.2991/iccie-18.2019.29

Suryanti, S., Mariana, N., Yermiandhoko, Y., \& Widodo, W. (2020). Local wisdom- based teaching material for enhancing primary students ' scientific literacy skill. Jurnal Prima Edukasia, 8(1), 96-105. https://doi.org/10.21831/jpe.v8i1.32898

Sutisna, D., Widodo, A., Nursaptini, N., Umar, U., Sobri, M., \& Indraswati, D. (2020). An analysis of the use of smartphone in students' interaction at senior high school. Proceedings of the 1st Annual Conference on Education and Social Sciences (ACCESS 2019), 465(Access 2019), 221224. https://doi.org/10.2991/assehr.k.200827.055 
Jurnal Prima Edukasia, 9 (2), 2021 - 232

Arif Widodo, Nursaptini Nursaptini, Muhammad Erfan

Widodo, A. (2020). Nilai budaya ritual perang topat sebagai sumber pembelajaran IPS berbasis kearifan lokal di sekolah dasar. Gulawentah:Jurnal Studi Sosial, 5(1), 1-16. https://doi.org/10.25273/gulawentah.v5i1.6359

Widodo, A., Maulyda, M. A., Fauzi, A., Sutisna, D., Nursaptini, N., \& Umar, U. (2020). Tolerance education among religious community based on the local wisdom values in primary schools. Proceedings of the 1st Annual Conference on Education and Social Sciences (ACCESS 2019), 465(Access 2019), 327-330. https://doi.org/10.2991/assehr.k.200827.082

Widodo, A., Royana, A., Maulyda, M. A., Erfan, M., \& Nursaptini, N. (2020). Silaq mace: Community library activities in improving reading habits of Sasak adolescents. 4th Sriwijaya University Learning and Education International Conference (SULE-IC 2020), 513, 183-189.

Widodo, A., \& Umar, U. (2020). Membentuk nilai-nilai keberagaman melalui kultur madrasah inklusi. JURNAL PENDIDIKAN ISLAM AL-ILMI, 3(2), 107-124. https://doi.org/https://doi.org/10.32529/al-ilmi.v3i2.743

Widodo, A., Umar, U., Sutisna, D., \& Tahir, M. (2020). Primary school teacher prospective perception of Sasambo local script preservation in NTB. Jurnal Pendidikan Dan Kebudayaan Missio, 12(2), 116-129. https://doi.org/10.36928/jpkm.v12i2.424

Yasa, I. M. A. (2020). Upacara Perang Topatdi Pura Lingsar Kecamatan Lingsar Kabupaten Lombok Barat. Media Bina Ilmiah, 14(9), 3179-3190. 